\title{
Paradoxical sleep deprivation changes testicular malondialdehyde and caspase- 3 expression in male rats
}

\author{
Fitranto Arjadi*, Ginus Partadireja**, Lientje Setyawan Maurits***, \\ and Mulyono Pangestu****
}

\section{ABSTRACT}

\section{BACKGROUND}

Sleep deprivation is a significant problem among adult men and is considered as a risk factor for several diseases. Paradoxical sleep deprivation (PSD) induces Leydig cell apoptosis through elevation of corticosterone, with testicular malondialdehyde (MDA) and Leydig cell caspase- 3 expression as parameters. The aim of this study was to observe testicular MDA level and caspase-3 expression treated with paradoxical sleep deprivation (PSD), immobilization, and footshock stress and to determine the stress model with a significant effect in white male rats (Rattus norvegicus).

\section{METHODS}

This experimental randomized study of posttest only with control group design was conducted on 24 white male Wistar strain rats, randomly allocated into four treatment groups, i.e. control (K1) without any stress treatment, PSD (KII), immobilization (KIII), and footshock stress (KIV). Treatments were given for 25 days to produce chronic stress. Testicular MDA concentration was examined by the ELISA method while caspase3 was examined by the TUNEL method.

\section{RESULTS}

Mean testicular MDA concentration with one-way ANOVA test showed differences in means between the groups $(\mathrm{p}=0.000)$ and post hoc TukeyHSD test showed significant results between PSD stress group versus control, immobilization and footshock stress groups. One-way ANOVA test showed a significant difference in caspase-3 expression in at least two treatment groups $(\mathrm{p}=0.008)$ and post-hoc Tuckey-LSD test showed significant differences between controls and all stress groups.

\section{CONCLUSION}

Sleep deprivation is a type of stress inducing changes in testicular MDA concentration and caspase- 3 expression in male rat testes.

\section{*Anatomy Department,}

Faculty of Medicine and Health Sciences,

Jenderal Soedirman University, Purwokerto

**Physiology Department, Faculty of Medicine,

Gadjah Mada University, Yogyakarta

***Department of Occupational Health, Faculty of Medicine, Gadjah Mada University, Yogyakarta ****Education Programme Reproduction and Development c/o Monash Institute of Medical Research, Australia

\section{Correspondence:}

dr. Fitranto Arjadi, MKes. Anatomy Department,

Faculty of Medicine and Health Sciences,

Jenderal Soedirman University Kampus Berkoh, Purwokerto 53146

Phone : +62281-622022 /

+628156996806

Email: f.arjadi@yahoo.com

Univ Med 2015;34:87-95

DOI: $10.18051 /$ UnivMed.2016.v35.87-95 pISSN: 1907-3062 / eISSN: 2407-2230

This open access article is distributed under a Creative Commons Attribution-Non Commercial-Share Alike 4.0 International License

Keywords: Caspase- 3 expression, stress, testicular malondialdehyde, male rat 


\section{Paradoxical sleep deprivation mengubah kadar malondialdehid testis dan ekspresi caspase-3 pada tikus jantan}

\section{ABSTRAK}

\section{LATAR BELAKANG}

Sleep deprivation merupakan masalah penting bagi laki-laki dewasa dan merupakan faktor risiko bagi beberapa penyakit. Paradoxical sleep deprivation (PSD) stres menyebabkan apoptosis sel Leydig akibat peningkatan kadar kortikosteron dengan parameter kadar MDA testis dan caspase-3. Tujuan penelitian adalah menyelidiki kadar MDA testis dan ekpresi caspase-3 (Rattus norvegicus) jantan yang diberi perlakuan stres PSD, stres imobilisasi dan stress footshock pada tikus putih jantan.

\section{METODE}

Metode penelitian adalah eksperimental dengan posttest only with control group design. Tikus putih jantan strain Wistar sebanyak 24 ekor dibagi 4 kelompok perlakuan; kontrol (KI) yaitu kelompok yang tidak diberi perlakuan stres, kelompok stres PSD (KII), kelompok stres imobilisasi (Kelompok III), dan kelompok stres footshock (KIV). Perlakuan diberikan selama 25 hari untuk menghasilkan stres kronik. Kadar MDA testis diperiksa menggunakan metode ELISA sedangkan caspase-3 menggunakan metode TUNEL.

\section{HASIL}

Hasil rerata pengukuran kadar MDA testis dengan One Way ANOVA menunjukkan perbedaan rata-rata antara kelompok $(p=0,000)$ dan uji Post Hoc Tukey HSD menunjukkan rata-rata kadar MDA pada stres PSD berbeda signifikan dengan kelompok kontrol, imobilisasi dan footshock. Hasil uji ANOVA menunjukkan ada perbedaan yang bermakna rata-rata ekspresi caspase-3 sel Leydig antara tiap kelompok data $(p=0,008)$ dan dilanjutkan dengan uji Post-Hoc Tuckey-LSD ada perbedaan rerata jumlah caspase-3 antara kelompok kontrol dengan semua perlakuan.

\section{KESIMPULAN}

Paradoxical sleep deprivation merupakan salah satu jenis stress yang mampu mengubah kadar MDA pada testis dan ekspresi caspase-3 pada testis tikus jantan

Kata kunci : Stres, MDA testis, ekspresi caspase-3, tikus jantan

\section{INTRODUCTION}

At the molecular level, male infertility occurs because of abnormal mitochondrial deoxyribonucleic acid (DNA) and apoptosis mechanism. ${ }^{(1)}$ When apoptosis is improperly activated or regulated in the testis, infertility can result. Pinpointing how environmental conditions can affect apoptosis is important for the advancement of preventive medicine and behavioral science, especially as there are potentially harmful environments in workplaces. Moreover, familiarity with stressful conditions in workplaces and with testicular processes, especially the induction of apoptosis, is essential for promoting male fertility. In male patients with idiopathic infertility, reactive oxygen species (ROS)-induced sperm damage is associated with increased apoptosis. ${ }^{(2)}$

Stress exposure can increase the concentration of cortisol which can disturb the testis by reduction of Leydig cell numbers and 
inducing apoptosis by glucocorticoid receptors ${ }^{(3)}$ and also by reducing the quality of Sertoli cells which can decrease the production of germinal cells, depress spermatogenesis, and finally can cause infertility. ${ }^{(4)}$ High glucocorticoid concentrations during the stress period can induce Leydig cell apoptosis by various mechanisms, such as activation of the Fas system, cleavage of procapase-3, removal of mitochondrial membrane potential (DeltaPsi) and elevation of ROS concentration. ${ }^{(3)}$ One of the apoptosis markers is the elevated expression of caspase-3 (the active form of procaspase-3). ${ }^{(5)}$

Work stress induces higher oxidative stress and stimulates the formation of high levels of ROS. ${ }^{(6)}$ The main target of ROS are lipids, such as in testiscular tissues which have high amounts of unsaturated fats which in the end can influence the capacity of the germinal cells to produce spermatozoa and to initiate the process of Leydig cell steroidogenesis. ${ }^{(7)}$ The high ROS concentrations activate lipid peroxidation, which ultimately produces hydrogen peroxide $\left(\mathrm{H}_{2} \mathrm{O}_{2}\right)$, exactly in the form of malondialdehyde (MDA), a cytotoxic oxidant in the body. ${ }^{(8)}$ Testicular MDA level has been used as biomarker to measure the degree of oxidative stress ${ }^{(9)}$ and to describe testicular tissue damage. ${ }^{(10)}$

The present research objective was to evaluate the effect of work environment stress on the concentrations of testicular MDA and caspase3 in male rats. In the experimental animals, sleep deprivation stress was implemented with the paradoxical sleep deprivation (PSD), immobilization and footshock tests. In the experimental animals, an analogous form of working stress is the lack of sleep which is induced with the PSD test as a form of physical and psychological stressor. The sedentarian pattern in office workers was modeled with the immobilization test as a form of social, physical, and psychological stressor, and high risk work with the footshock test as a form of physical stressor. The electric foot stress is usually used as a stressor in animal models such as conditioned fear stress and learned helplessness. ${ }^{(11)}$

\section{METHODS}

\section{Research design}

This research used an experimental post test only design with completely randomized sampling repeated five times. This research was conducted from January to December 2013 at the animal house of the Medical Faculty of Jenderal Soedirman University, and at the Biochemistry Laboratory and Anatomical Pathology Laboratory, Medical Faculty, Gadjah Mada University.

\section{Animals}

A total number of 24 male Wistar albino rats (six rats for each treatment), aged 3-4 months and weighing 200-300 grams, were obtained from the animal house of the Faculty of Pharmacy, Gadjah Mada University. The sample size was determined by Federer's formula (t-1) $(\mathrm{r}-1)>15$ where $\mathrm{t}=$ number of treatments and $r=$ number of replications.

\section{Intervention}

The rats were placed in stainless steel cages with the dimensions $23 \times 13 \times 16 \mathrm{~cm}$ for 1 week with controlled lighting (12 hours light/12 hours dark cycle) and temperature $\left(21-24^{\circ} \mathrm{C}\right)$ and received food and water ad libitum. ${ }^{(12)}$ The rats were placed in cages of the same size, form, and material. The experimental animals were divided into four treatment groups: KI as the control group, in which the rats were kept in a wide cage with their normal sleep pattern, and the groups KII, KIII, and KIV which were subjected to the PSD, immobilization and footshock stress tests, repectively. In group KII the rats were treated with PSD stress using the Modified Multiple Platform Method (MMPD), by placing the rats in a $123 \mathrm{x}$ $44 \times 44 \mathrm{~cm}$ tank containing water to a height of 1 $\mathrm{cm}$ and having 14 platforms, where each platform was separated by a distance of $10 \mathrm{~cm}$, so the rats could move freely inside the cage, jump from platform to platform, and interact with the other rats in the cage. A muscle atonia-inducing device was turned on automatically every 10 minutes, 
so that when the rats begin to sleep, they will fall down into the water and awaken from sleep. This cycle was done in 18 hours from 04.00 until 22.00 o'clock and after that the rats were returned to their regular cages, in which they sleep for 6 hours. ${ }^{(13)}$ In group KIII, in which the rats were treated with immobilization stress, the rats were placed for 1 hour, from 09.00 until 10.00, in a transparent cylinder, $21 \mathrm{~cm}$ in length and $6 \mathrm{~cm}$ in diameter, with ventilation holes at the sides. ${ }^{(13)} \mathrm{In}$ group KIV, the footshock stress group, the rats were placed in an $14 \times 25 \times 28 \mathrm{~cm}$ acrylic box, in which an 0.1 second electric current of $5 \mathrm{~mA}$ was applied to the base for 1 hour/day from 09:00 until 10:00. Each rat was shocked 4-6 times at different intervals, which were changed every 5 minutes to avoid anticipation by the rats. ${ }^{(14)}$ Each treatment (KII, KIII and KIV) was given for 25 days to induce a chronic stress effect. ${ }^{(3)}$ The rats were then anesthetized with ether, decapitated, and incised to harvest the left testicle, which was cleaned in $\mathrm{NaCl}$ solution, weighed, and preserved in Bouin solution.

\section{Measurement of testicular MDA}

Measurement of testicular MDA was performed by means of a kit (Catalog Number: 201-11-0157, Shanghai Sunred Biological Technology, China). The isolated testis was weighed, PBS solution was added at the ratio of 50-100 mg testis to $1 \mathrm{ml} \mathrm{PBS}$, and the testis was mashed in a mortar until homogenous, placed in a microtube and centrifuged at $4000 \mathrm{rpm}$ for 5 minutes, after which the supernatant solution was stored at $-80{ }^{\circ} \mathrm{C}$. The testicular tissue MDA concentration was measured by the ELISA method with the double-antibody sandwich technique.

\section{Caspase -3 expression}

Measurement of TUNEL caspase-3 expression was done in 50 fields of view of testis interstitial tissue at 400x magnification. The methods used were TUNEL and staining with anti caspase-3. A positive expression was shown by a brown color of the cytoplasm. Observations were done using a Nikon Eclipse E100 ${ }^{\circledR}$ microscope with Optilab ${ }^{\circledR}$ and Image Raster software version 2.1 .

\section{Data analysis}

Univariate analysis was done on the mean testicular MDA concentration and caspase-3 expression data, data normality and homogeneity were analyzed with Shapiro Wilk and Levene's test. Comparisons of mean values was analyzed by one-way ANOVA and each treatment compared with post-hoc Tukey test, and if there was a difference between treatments, the analysis was to be continued with Duncan's multiple range test (DMRT) at a value of $\mathrm{p}<0.05$.

\section{Ethical clearance}

All experimental procedures were approved by the Research Ethics Committee of Medical and Health Sciences of Jenderal Soedirman University.

\section{RESULTS}

The data was collected without drop outs and the caspase- 3 counts were conducted by the investigator and two other observers to yield valid values. Normality tests on the results of caspase-3 expression and testicular MDA using the Saphiro-Wilk test showed the data to be normally distributed. The variance test using Levene's test showed equal data variances $(\mathrm{p}=0.146)$, so that a parametric test using oneway ANOVA could be done. The mean MDA concentrations analyzed with parametric oneway ANOVA showed significant differences in MDA concentrations between groups $(\mathrm{p}=0.000)$ (Table 1).

Post hoc Tukey HSD test showed significant differences between the PSD group on the one hand and the control, immobilization stress and footshock stress groups on the other (Table 2). The results of ANOVA test for Leydig cell caspase-3 expression showed significant differences between all treatment groups $(p=0.008)$. Post-hoc Tuckey-LSD showed that mean Leydig cell caspase-3 expression in three of the treatment groups was significantly 
Table 1. Mean testicular MDA and number of caspase-3 expression by treatment groups

\begin{tabular}{|c|c|c|c|c|c|}
\hline & \multicolumn{4}{|c|}{ Treatment grous } & \multirow[b]{2}{*}{$\mathbf{p}$} \\
\hline & $\begin{array}{c}\begin{array}{c}\text { Control } \\
(n=6)\end{array}\end{array}$ & $\begin{array}{c}\text { PSD } \\
(\mathrm{n}=6)\end{array}$ & $\begin{array}{c}\text { Immob biliza tion } \\
(n=6)\end{array}$ & $\begin{array}{c}\text { Footshock } \\
(n=6)\end{array}$ & \\
\hline Testicular MDA (ng/mL) & $10.61 \pm 0.93$ & $13.43 \pm 0.83$ & $11.01 \pm 0.35$ & $10.34 \pm 0.61$ & 0.000 \\
\hline Number of caspase- 3 & $3.82 \pm 0.62$ & $2.30 \pm 0.46$ & $2.71 \pm 0.75$ & $3.04 \pm 0.15$ & 0.008 \\
\hline
\end{tabular}

Note: Values are mean $\pm \mathrm{SD} ; \mathrm{MDA}=$ malondialdehyde; $\mathrm{PSD}$ = paradoxical sleep deprivation

different from the control group, with the lowest mean in the KII group as compared with the control group $(\mathrm{p}<0.05)$ (Table 2$)$.

Compared with the controls, the number of caspase-3 expression decreased in all stress models, with the lowest number in the PSD stress group (Figure 1).

\section{DISCUSSION}

The highest mean testicular MDA concentration and lowest caspase-3 expression was in the PSD stress group, showing that PSD stress increases oxidative stress which can induce lipid peroxidation reaction and damage the antioxidant mechanism of the body. Paradoxical sleep deprivation increases in MDA level and may enhance the metabolic rate and in turn increase free radical generation and induce cell damage. Oxidative stress caused by PSD induction decreases the damage of endogenous antioxidant mechanism by inhibition of G6DP (glucose- 6 diphosphatase) and stimulation of a larger lipid peroxidation reaction. The lipid peroxidation reaction is a cascade of reactions that can produce free radicals and continuous peroxidation, with MDA as the end product. These results suggest that sleep has an antioxidative role. Free radicals which accumulate during wakefulness are removed during sleep and this is accomplished by decreasing the rate of free radical formation and increasing the efficiency of endogenous antioxidant mechanisms. ${ }^{(15)}$ Paradoxical deprivation increases early morning pineal melatonin, which induces apoptosis through activation of caspase-3, caspase-6, caspase- 7 , and caspase-9, in association with up-regulation of the pro-apoptotic factor Bax and also with the release of cytochrome $\mathrm{c}$ from mitochondria. ${ }^{(16)}$

Stress disturbs the reproductive system and decreases the numbers of Leydig cell because of the increase in glucocorticoids induced by PSD stress. ${ }^{(17)}$ Glucocorticoids induce the apoptotic process in mature and immature Leydig cells because of the high numbers and high sensitivity of the glucocorticoid receptors. Glucocorticoids cause Leydig cell apoptosis by several mechanisms such as Fas system activation, procaspase-3 activation, reduction of mitochondrial membrane potential and elevation of ROS concentration. Caspase- 3 is a protein in the caspase cascade pathway that is important in apoptosis and is activated by caspase 8 and 9 . Procaspase-3, which is in the form of an active enzyme, can cleave into a new subunit, caspase3 , which can activate caspase 6 and 7. Caspase3 with caspase 6 and 7 is proteolytic and can induce apoptosis. ${ }^{(18)}$

Table 2. Post hoc test LSD for MDA and caspase-3 by treatment groups

\begin{tabular}{lcc}
\hline \multicolumn{1}{c}{ Treatment gro u } & TesticularMDA (p) & Number of casp ase-3 (p) \\
\hline Control - PSD & $0.000^{*}$ & $0.045^{*}$ \\
Control - Im mobilization & 0.877 & $0.010^{*}$ \\
Control - Footshock & 0.965 & $0.001^{*}$ \\
PSD -Imm obilization & $0.000^{*}$ & 0.366 \\
PSD -Foot shock & $0.000^{*}$ & 0.055 \\
Im mobilizati on -F oot dhock & 0.542 & 0.287 \\
\hline
\end{tabular}

Note $*=p<0.05$ means significantly different; MDA = malondialdehyde; PSD = paradoxical sleep deprivation 

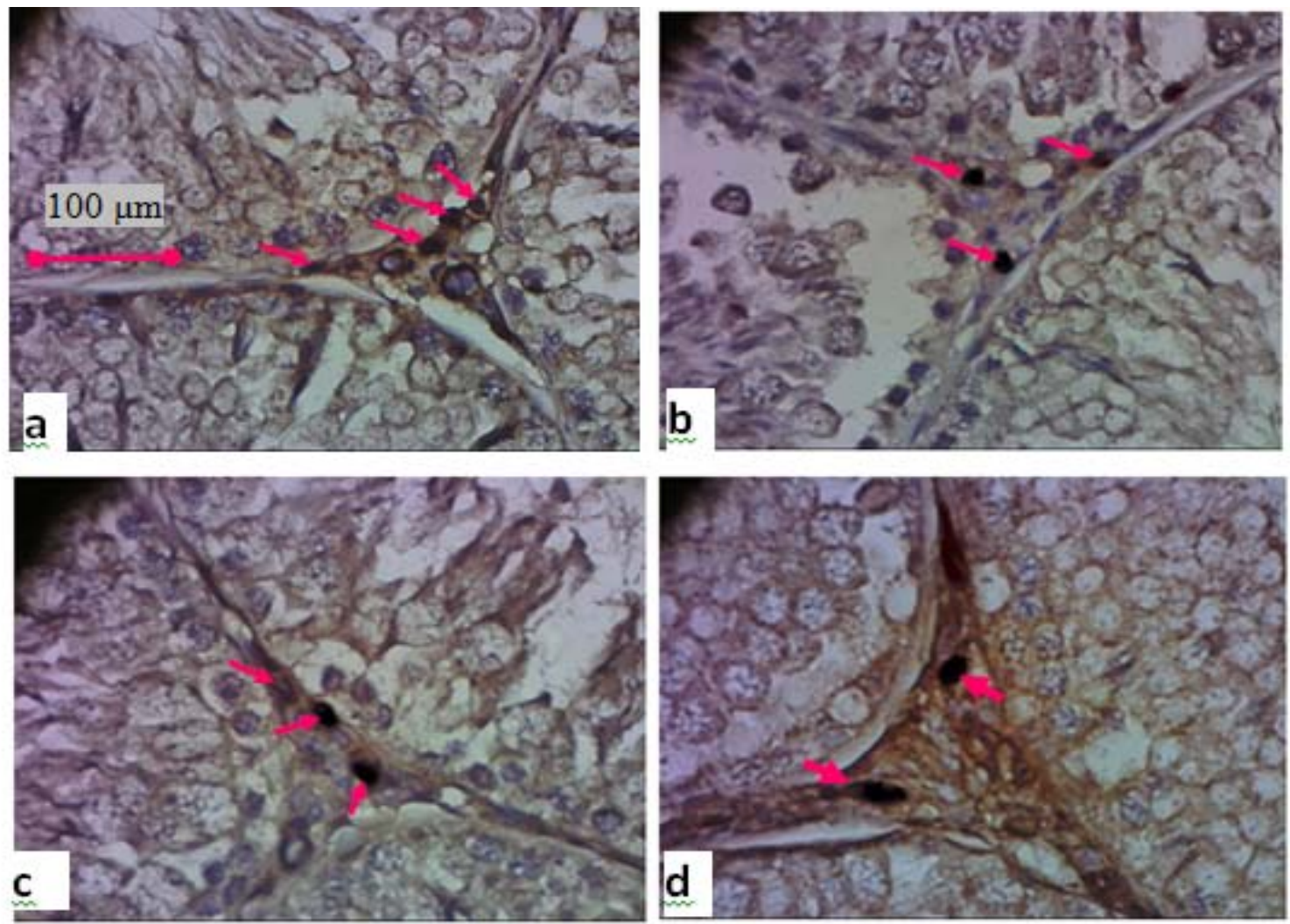

Figure 1. Leydig cell caspase-3 of Rattus norvegivus interstitial testis tissue. Red arrows indicate caspase-3 expression with positive expression shown by brown cytoplasm. Stain: IHC. Magnification: 400 X.

Note: a) control; b) PSD stress; c) immobilization stress; d) footshock stress

In immobilization stress, the study used TUNEL and active caspase-3 staining methods. The results showed that apoptosis was significantly higher in the stress groups than in the control group, with the markers being the number of TUNEL (+) and caspase $3(+)$ cells, which was increased significantly in the stress groups, in comparison with the cells in the control group. The study demonstrated the occurrence of testicular damage on the basis of elevated MDA levels. The results showed that there is a relationship between immobilization stress on the one hand and induction of apoptotosis and lipid peroxidation on the other. ${ }^{(19)}$ Leydig cell apoptosis is not elevated if endogenous corticosterone is low, proving that Leydig cell apoptosis occurs if corticosterone concentration is elevated, which can reduce testosterone concentration. ${ }^{(3)}$ Reduced testosterone in immobilization stress also can elevate spermatocyte apoptosis by activation of caspase- 3 so the normal hormonal concentration is still needed for steroidogenesis but in this research the effect was stronger in the PSD stress model. ${ }^{(2)}$

Footshock stress as physical stress showed a significant increase in MDA levels on the $30^{\text {th }}$ day of the experiment compared with the 1st day, but no significant difference was observed at any time between MDA levels of the control and physical stress groups. ${ }^{(20)}$ The effect of footshock stress on cell Leydig apoptosis remains unclear, and studies and references about the mechanism are also still limited.

All well-known stress models may elevate glucocorticoid levels, therefore causing Leydig cell apoptosis by intrinsic and extrinsic pathways. Apoptosis by the extrinsic pathway (death receptor pathway) is initiated by the elevation of glucocorticoids which can continue to induce release of death signal proteins such as Fas-Ligand (Fas-L) ${ }^{(3)}$ The release of Fas-L causes interaction 
between Fas and Fas-L, which can form FasAssociated Death Domain (FADD). FADD formation cause formation of death-inducingsignaling-complex (DISC) which can cause activation of caspase- $8 .{ }^{(21)}$ Apoptosis by the intrinsic pathway (stress-induced, mitochondrion pathway) is marked by the reduction in mitochondrial membrane potential and the formation of superoxide anions (part of ROS). ${ }^{(3)}$ The intrinsic pathway is initiated by the cleavage of Bid (part of Bcl-2) and can cause the loss of mitochondrial membrane potential so that cytochrome $\mathrm{C}$ can be released. Released cytochrome $\mathrm{C}$ can form apoptosomes which can activate caspase- 9 . Active caspase- 8 and 9 can cause activation of procaspase-3 into caspase-3, which forms two subunits that complex into a tetramer with a number of cellular substrates, leading to Leydig cell apoptosis. Leydig cell apoptosis is marked by abnormal morphologic changes, such as reduction of cellular volume, chromatin condensation, mitochondrial disintegration, swelling of the cell membrane, and cytoplasm vacuolization and biochemical changes, i.e. exposure of phosphatidylserine in the plasma membrane, activating caspase, and resulting in DNA cleavage. ${ }^{(2)}$

Reduction in sleeptime can elevate the concentration of melatonine, which is known to influence testicular activity and gonadotropin secretion. Melatonin has a direct effect on $\mathrm{GnRH}$ neuron receptors to induce expression of $\mathrm{GnIH}$, which can inhibit $\mathrm{LH}$ release and cause a reduction in testicular function. ${ }^{(22)}$ Elevation of melatonin concentration can reduce Leydig cell number and function by two mechanism, i.e. by reduction of calcium ion from the cytosol and by inhibition of cAMP activity in steroidogenesis. ${ }^{(23)}$

The elevation of glucocorticoid concentration because of oxidative stress can suppress the antiapoptotic group and can the activate proapoptotic group. These can cause mitochondrial membrane permeability change and reduction of membrane potential so that leakage occurs in cytochrome $\mathrm{C}$ protein. Cytochrome $\mathrm{C}$ protein release into the cytosol can activate the mitochondrial pathway by activation of caspase 9. Caspase 8 and caspase 9 can activate caspase3 so that the cell will enter the degradation phase and finally, cell death can occur. The morphologic changes in the cell that undergoes apoptosis consist of reduction in cellular volume, chromatin condensation, apoptotic body formation and mitochondrial disintegration as a result of caspase3 activation. Caspase- 3 is a protease with proteolytic abilities and can cause cleavage of many intracellular substrates. ${ }^{(18)}$ Caspase-3 expression is also elevated in the penis and the prostate upon reduction of testosterone because of Leydig cell damage. ${ }^{(24)}$

One the limitation of the study is that no stereological methods were used, of which the advantages are that the sampling is uniform to ensure that all cells in the testis have equal probabilities of being sampled and no assumptions about shape, size or orientation of the cells or shrinkage of the testis during histological processing are required. The conventional counting method is morphometric and may severely bias the results in unpredictable ways (e.g. the results are influenced by differential tissue shrinkage in hormone-treated rats and control rats). ${ }^{(25)}$

The results of this study could be useful to company doctors, psychiatrists and andrologists in promoting health status, particularly for fertility problems in male workers. In future, we will investigate the effect of stress models in infertile human males and the use of traditional antioxidants to improve the fertility status. The study of the various workstress types in humans is very limited because of inadequacy of samples, low participancy, selection and recall bias, ethic problems and no exact clues to the source of the stressors.

\section{CONCLUSION}

This study reveal that sleep deprivation caused alterations in testicular MDA concentration and caspase- 3 expression in male rats. 


\section{CONFLICTS OF INTEREST}

None declared.

\section{ACKNOWLEDMENTS}

The authors would like to express their thanks to the Directorate General of Higher Education, Ministry of Education and Culture for funding through the Hibah Disertasi Doktor scheme for 2013 and to the Department of Biochemisty, Medical and Health Sciences Faculty, Jenderal Soedirman University, and the Pathological Anatomy Laboratory, Medical Faculty, Gadjah Mada University, for research facilities.

\section{REFERENCES}

1. Nakada K, Sato A, Yoshida K, et al. Mitochondria-related male infertility. PNAS 2006;103:15148-53.

2. Premendu P, Huang L, Kashou A, et al. Environmental toxicants and testicular apoptosis. Reprod Sci J 2011;3:114-24.

3. Arjadi F, Soejono SK, Pangestu M. Paradoxical sleep deprivation decreases serum testosterone and Leydig cells in male rats. Univ Med 2014;33: 27-35.

4. Pfaff TJ, Rhodes MB, Weinbauer GF. Inhibin B as a marker of Sertoli cell damage and spermatogenic disturbance in the rat. Birth Defects Res 2013;98:91-103.

5. Ghavami S, Hashemi M, Ande SR, et al. Apoptosis and cancer: mutations within caspase genes. J Med Genet 2009;46:497-510.

6. Lima AMA, de Bruin VMS, Rios ERV, et al. Differential effects of paradoxial sleep deprivation on memory and oxidative stress. Naunyn-Schmiedeberg's Arch Pharmacol 2014; 378:399-406.

7. Aitken RJ, Roman SD. Antioxidant systems and oxidative stress in testes. Oxid Med Cell Longev 2008;1:15-24.

8. Pusparini CW, Aulanni'am, Oktavianie DA. Kadar malondialdehyde (MDA) dan gambaran histopatologi organ paru pada hewan model tikus (Rattus norvegicus) asma dengan induksi lipopolisakarida. UBJ Chem 2012;1:1-7.

9. Sakr SA, Somaya YS. Carbendazim-induced testicular damage and oxidative stress in albino rats: ameliorative effect of licorice aqueous extract. Toxicol Ind Health 2014;30;259-67.

10. Duru FIO, Noronha CC, Akinwande AI, et al. Effects of torsion, detorsion and melatonin on testicular malondialdehyde level. West African J Med 2007;26:312-5,

11. Hipolide DC, Suchecki D, Pimentel DCP, et al. Paradoxical sleep deprivation and sleep recovery: effects on the hypothalamic-pituitary-adrenal axis activity, energy balance and body composition of rats. J Neuroendocrinol 2006; 18 : 231-8.

12. Willems RA. Regulatory issues regarding the use of food and water restriction in laboratory animals. Lab Anim 2009;38:325-8.

13. Andersen ML, Silva A, Kawakami R, et al. The effects of sleep deprivation and sleep recovery on pain thresholds of rats with chronic pain. Sleep Sci 2009;2:82-7.

14. Dagyte G, Van der Zee EA, Postema F, et al. Chronic but not acute foot-shock stress leads to temporary suppression of cell proliferation in rat hippocampus. Neuroscience. 2009;162:904-13.

15. Thamaraiselvi K, Mathangi DC, Subhashini AS. Effect of increase in duration of REM sleep deprivation on lipid peroxidation. Int J Biol Med Res 2012;3:1754-9.

16. Perdomo J, Cabrera J, Estévez F, et al. Melatonin induces apoptosis through a caspase-dependent but reactive oxygen species-independent mechanism in human leukemia Molt-3 cells. J Pineal Res 2013;55:195-206.

17. Alvarenga TA, Monica LA, Javier VM, at al. Food restriction or sleep deprivation: which exerts a greater inûuence on the sexual behaviour of male rats? Behav Brain Res 2009;202:26671.

18. Shaha C, Tripati R, Mishra DP. Male germ cell apoptosis: regulation and biology. Phil Trans R Soc B 2010;365:1501-15.

19. Bitgul G, Tekmen I, Keles D, et al. Protective effects of resveratrol against chronic immobilization stress on testis. ISRN Urol 2013; 1-10.

20. Jafari M, Salehi M, Zardooz H, et al. Response of liver antioxidant defense system to acute and chronic physical and psychological stresses in male rats. XCLI J 2014;13:161-71.

21. Thorburn A. Tumor necrosis factor-related apoptosis-inducing ligand (TRAIL) pathway signaling. J Thorac Oncol 2007;2:461-5.

22. Tsutsui K, Ukena K. Hypothalamic LPXRFamide peptides in vertebrates: identification, localization and hypophysiotropic activity. Peptides 2006;27:1121-9. 
23. Ahmed NA. Effect of short photoperiod on the Leydig cells of rat's testis: ultrastructural and immunohistochemical study. Egyptian J Histol 2008;31:354-1.
24. Taufiqurrachman. Decreased expression of caspase- 3 in penis and prostat tissue of rat after the treatment of Buceng (Pimpinella alpina Molk and Euricoma lungifolia Jack). Med J Indones 2013;22:2-8. 